\title{
ASSESSMENT OF A PC BASED SYSTEM TO MEASURE SAP FLOW IN HERBACEOUS PLANTS IN REAL TIME
}

\author{
EVALUACIÓN DE UN SISTEMA BASADO EN PC PARA MEDIR FLUJO DE SAVIA \\ EN TALLOS HERBÁCEOS EN TIEMPO REAL
}

\author{
José F. Reyes ${ }^{1}$; Wilson D. Esquivel ${ }^{1}$; Américo O. Franco $^{1}$
}

\begin{abstract}
RESUMEN
Se diseñó y evaluó un sistema para medir la transpiración de plantas herbáceas en tiempo real. El sistema propuesto incluye un sensor de flujo de savia, una interface electrónica y un programa computacional en Codigo $\mathrm{C}++$. El sistema utiliza un transductor basado en termocuplas y una interface diseñada para procesar los datos del transductor obtenidos a través de la puerta paralela de un computador personal (PC). Para evaluar el desempeño del sistema se utilizaron plantas de maíz (Zea mays L.) de once semanas, cultivadas en invernadero. El sistema basado en PC se calibró utilizando datos experimentales obtenidos con datalogger y evaluó comparando sus resultados con los del método de diferencia de pesadas de la planta. El error del sistema para estimar flujo de savia fue de $8 \%$, el cual es similar a la exactitud del método que utiliza un datalogger. La metodología evaluada ofrece la posibilidad de medir en tiempo real las pérdidas de agua por transpiración y puede ser implementada principalmente para cultivos que crecen en invernadero para aumentar la productividad y disminuir los riesgos de enfermedades del cultivo. El sistema basado en PC es una opción para diseñar un sistema comercial de irrigación a un costo global bajo, ya que utiliza un computador convencional y componentes electrónicos de bajo costo.
\end{abstract}

Palabras clave: Flujo de savia, transpiración de plantas, transductor de flujo, termocuplas.

\begin{abstract}
A system to measure the transpiration of herbaceous plants in real time was designed and evaluated. The proposed system includes a sap flow sensor, an electronic interface card and a computational C++ code. The system uses a transducer based on thermocouples and an interface designed to process the data from the transducer through the parallel port of a personal computer (PC). In order to evaluate the performance of the system, eleven weeks old maize plants (Zea mays L.), growing in a greenhouse were used. The $P C$ based system was calibrated with respect to data from the data logger and evaluated by comparison with results obtained by differential plant weighting. Error of the system to estimate sap was lower than $8 \%$, which is similar to the accuracy of the data logger methods. The evaluated methodology offers a real time possibility to determine water losses due to transpiration and it can be implemented mainly for crops growing in greenhouses to optimize productivity and minimize plant diseases. The PC based method is an option to design a commercial irrigation control system at a relatively low overall cost, since a conventional computer and cheap electronic devices are utilized.
\end{abstract}

Key words: Sap flow, plant transpiration, flow transducer, thermocouples.

\section{INTRODUCTION}

In order to estimate crop water requirements, mathematical models or indirect measurements of transpiration are generally used. The mathematical models have difficulties to reproduce the not trivial phenomenon of the transpiration which requires instruments of high cost to feed these equations, as is the case of the Penman-Monteith's model
(Allen et al., 1998). Some of the more utilized indirect methodologies to fast measurement of the water requirements of a crop are gravimetric, tensiometer, neutrometer and TDR, which permit to measure directly the amount of water in the ground. Another usual methodology measures the evaporation from a free surface of water in a tray of standard dimensions. An instrument of great exactitude is the lisimeter which allows to make

\footnotetext{
1 Facultad de Ingeniería Agrícola, Universidad de Concepción. Av. Vicente Méndez 595, casilla 537, Chillán, Chile, e-mail: jreyes@udec.cl
} 
a water balance that can be used to calibrate the tray of evaporation with respect to a reference crop. However because of its lack of portability the lisimeter is mainly used in agricultural research stations for discrete measurements.

The most commonly used methods for tree sap flow measurements are based on local heating and measuring of heat transfer by moving water. The equations applied to relate the temperature differences between selected points of the stem with the water mass flow have been derived in a either empirically or physically. Empirical calibration (Granier, 1985) is applied to a class of sap flow meter named heat dissipation probes. Other approach use a very simplified heat balance equation (Cermak, 1976) which is known as he heat balance method that may be applied either to the entire stem in the case of small trees, or to a restricted interior volume for trees of larger diameter (Herzog et al., 1997). This method can be implemented either with constant or variable power input (Green et al., 2003 and Kjelgaard et al., 1997). A third category of technique is the so called heat pulse method where the mass flow of sap is determined from the velocity of a short pulse of heat moving along xylem tissue though conduction and convection (Swanson, 1994).

The sap flow meter works very well with visible or exposed stems, being used in agricultural research, mainly in row crops (Rios, 1999; Gonzalez, 2000; Jeldres, 2000). One of the most used methodologies is the one used by Steinberg $e t$ al. (1989), in which the applied power was $0.9 \mathrm{~W}$ for Ficus benjamina with a diameter of $45.2 \mathrm{~mm}$, obtaining errors smaller than $4 \%$. Also Steinberg et al. (1990) obtained errors smaller than 5\% for Taxodium distichum and Ficus retusa where the diameter of the trunk varied from 32 to $45 \mathrm{~mm}$ and the electrical power delivered by the heater was 0.4 W. Steinberg et al. (1990) employed a set of thermocouples to be averaged with the purpose of measuring a more representative value. The same scheme is used by Hinckley et al. (1994), in Populus of 11 to 15 meters height and 8.3 to 15 centimetres of diameter. Devit and Berkowitz (1993), found errors between $8 \%$ and $20 \%$ for the same flow meter with three ornamentals species in short periods of measurement, due to the instability of the instrument early morning and at late afternoon. These values are greater than the ones obtained by Steinberg et al. (1990), Gutiérrez et al. (1994) and
Kjelgaard et al. (1997), whose errors were always smaller than $10 \%$ for longer periods of time. More recently, the influence of the parameters used to design the sap flow meter have been assessed by Reyes and Jeldres (2007), who obtained different accuracies by varying the power applied to the trunk and the distance between upstream and downstream thermocouples for small tress

In this study we propose to develop and evaluate an instrumentation system that includes a sap flow meter along with a computer interface and a computer code to control the functioning of the whole system. This simple architecture avoids the use of highly expensive data acquisition equipment (data logger). The computer program synchronizes the different modules of the electronic interface to monitor the flow of sap of the plant in real time allowing the autonomous operation of the system.

\section{METHODOLOGY}

\section{TRANSDUCER THEORY}

The method of the heat balance is based on the steady state regime of the water flow that passes through the stem. By means of the root system, the plant takes water and mineral substances from the ground to be then conducted upwards. All the water transported by the xylem is not estomatic transpiration since part of it corresponds to cuticle transpiration. The cuticle transpiration is important only in certain plants with a very thin cuticle, but in general it supposes less than $10 \%$ of the total transpiration. In addition, the flow in the phloem is several times smaller than in the xylem (Hess, 1980), thus it has a reduced effect in the heat balance. Therefore, almost the totality of the sap flow that passes through a section of the stem is transpirated through the leaves.

The method of heat balance adapted by Steinberg et al. (1990) consists of applying heat to a section of the stem and then quantifying the heat losses that take place in a partial volume of the stem. The scheme of the transducer is in Figure 1.

The device includes a heater, thermocouples, a thermal insulator, and solar insulation. The heat is transferred as much downstream as upstream by conduction. In addition, the sap flow in the xylem produces losses by convection, and finally a radial loss through the insulator exists. The thermal balance 


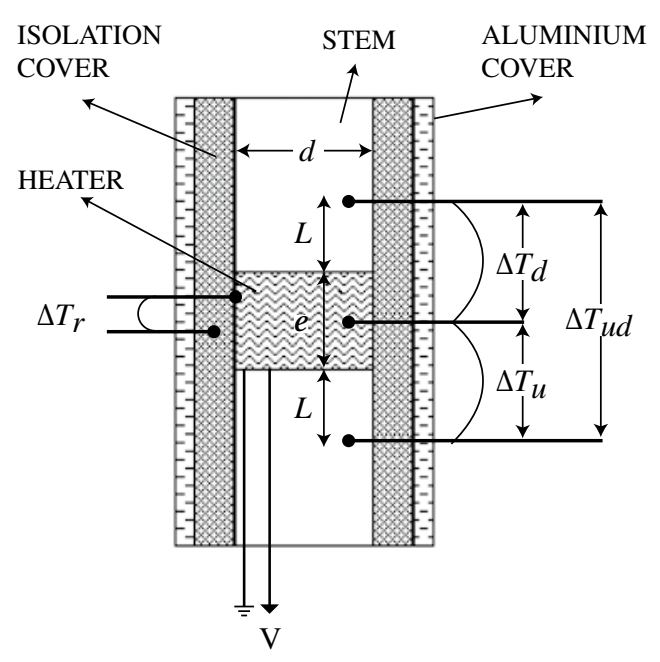

Figure 1. Diagram of the sap flow transducer used in the experience.

applied to a section of the stem of the plant gives the following well known expression for the sap flow (Jeldres, 2000):

$$
F=\left(\frac{V^{2}}{R}-\frac{K A\left(\Delta T_{d}+\Delta T_{u}\right)}{\Delta L}-K_{r} \Delta T_{r}\right) \frac{3600}{C p \Delta T_{u d}}
$$

Where $F$ is the sap flow rate $\left(\mathrm{g} \mathrm{h}^{-1}\right), K$ is the thermal conductivity of herbaceous plants $\left(\mathrm{W} \mathrm{m}^{-1}{ }^{\circ} \mathrm{C}^{-1}\right), A$ is the cross section of the stem $\left(\mathrm{m}^{2}\right), \Delta T_{u}$ is the temperature differential in the heater sector at a distance $L$ upwards $\left({ }^{\circ} \mathrm{C}\right), \Delta T_{d}$ is the temperature differential in the heater sector at a distance $L$ downwards $\left({ }^{\circ} \mathrm{C}\right), \Delta L$ is the separation between position $L$ upwards and $L$ downwards from the heater (m), $K_{r}$ is the radial conductance ( $\mathrm{W}^{\circ} \mathrm{C}^{-1}$ ) of the insulation, $\Delta T_{r}$ is the temperature differential between the external surface of the stem and the external surface of the insulating cover $\left({ }^{\circ} \mathrm{C}\right), V$ is the heater voltage $(\mathrm{V}), R$ is the heater resistance $(\Omega), C_{p}$ is the water specific heat $(4.19$ $\left.\mathrm{J} \mathrm{g}^{-1}{ }^{\circ} \mathrm{C}^{-1}\right), \Delta T_{u d}$ is the temperature difference up and down the heater $\left({ }^{\circ} \mathrm{C}\right)$ and 3600 is the number of second per hour.

In developing expression (1), the power applied to the heater is evaluated as:

$$
Q=\frac{V^{2}}{R}
$$

On the other hand, in equation (1), the radial conductance $\left(K_{r}\right)$ is determined during a period of zero or near zero sap flow using the following equation:

$$
K_{r}=\left(\frac{V^{2}}{R}-\frac{K A\left(\Delta T_{d}+\Delta T_{u}\right)}{\Delta L}\right) \frac{1}{\Delta T_{r}}
$$

\section{TRANSDUCER SET UP}

In order to install the sap flow transducer of Figure 1 the low part of the maize stem was used clearing a space from its leaves. Then a point on the stem was marked where a first thermocouple was inserted. Now the heater was wrapped around the stem along with the insertion of the first thermocouple in the stem at the heater centre. Immediately after two points were marked at an equal distance $\Delta L$ upper and under the edge of the heater where thermocouples to measure the temperature differential upstream and downstream were inserted. In order to measure the radial differential of temperature an inner thermocouple was installed on the centre of the heater. The whole sector of the sensor was then wrapped with a sticky tape thermal insulator followed by a polyurethane thermal insulator in order to prevent the heat losses from the sector. An outer thermocouple for measurement of the radial differential was inserted in the centre of the thickness of the polyurethane insulator. A layer of Aluminium foil was utilized as final cover of the whole measuring stem section to avoid the heating effect of the light incident radiation. Copper-constantan thermocouples of $0.13 \mathrm{~mm}$ diameter were used due to its high linearity in the temperature range of the system. A small thermocouple diameter was chosen to diminish the thermal inertia of the metallic joint and therefore the time constant of the dynamic response of the sensor.

\section{COMPUTER INTERFACE CARD}

An instrumentation interface system was designed and built to digitally monitoring the temperature differential from the thermocouples, along with the voltage supplied to the heater of the sensor. The general architecture of the interface card is schematised in Figure 2. The sap flow sensor yields values of tension corresponding to temperature differentials that are multiplexed to feed the input of a differential operational amplifier. The power to the sensor is supplied by a dual voltage source 
whose output voltage level can be varied between the day and the night to control the heating power to the stem which is read through a second multiplexer. The voltage signal from the flow sensor along with the heater voltage are sequentially converted to digital values by means of the analogous to digital converter whose output is acquired through the parallel port of the computer . Integrated components of the type DIP (Dual-In-line Package) were used. A dual type of four channels and 5 volts multiplexer model MC14052B was located after the flow sensor. These multiplexer performs the sequential transmission of a pair of signals corresponding to a voltage thermocouple differential by means of two digital control levels sent from the computer parallel port. A second multiplexer equivalent to the device previously mentioned was used to route to the computer either the voltage signal from the heater or the differential amplified signal from the thermocouples once at a time. The amplification of the temperature differential was accomplished with an operational differential amplifier INA111 powered with $\pm 12 \mathrm{~V}$. The voltage control circuit allows switching the power provided to the heating unit between two different levels using a switching signal from the parallel port of the computer. This connection is done through the RAS1210 double contact, single shot relays powered with $12 \mathrm{~V}$. The control signal from the computer parallel port drives a MPS-A13 bipolar transistor which acts on the contacts of the relays. Both the voltage differential from the thermocouples and the voltage source supplied to the heating unit are converted to 12 bits digital values by the $0-5 \mathrm{~V}$ analog to digital converter MAX191. The reading of this converter is done through the computer parallel port whose connections are shown in Figure 2. The parallel port provides a bus of data that allows 8 bits output of information, a status bus that makes possible the reading of 5 bits and a control bus by means of which it is possible bi-directional transmission of up to 4 bits of digital information. In order to be able to

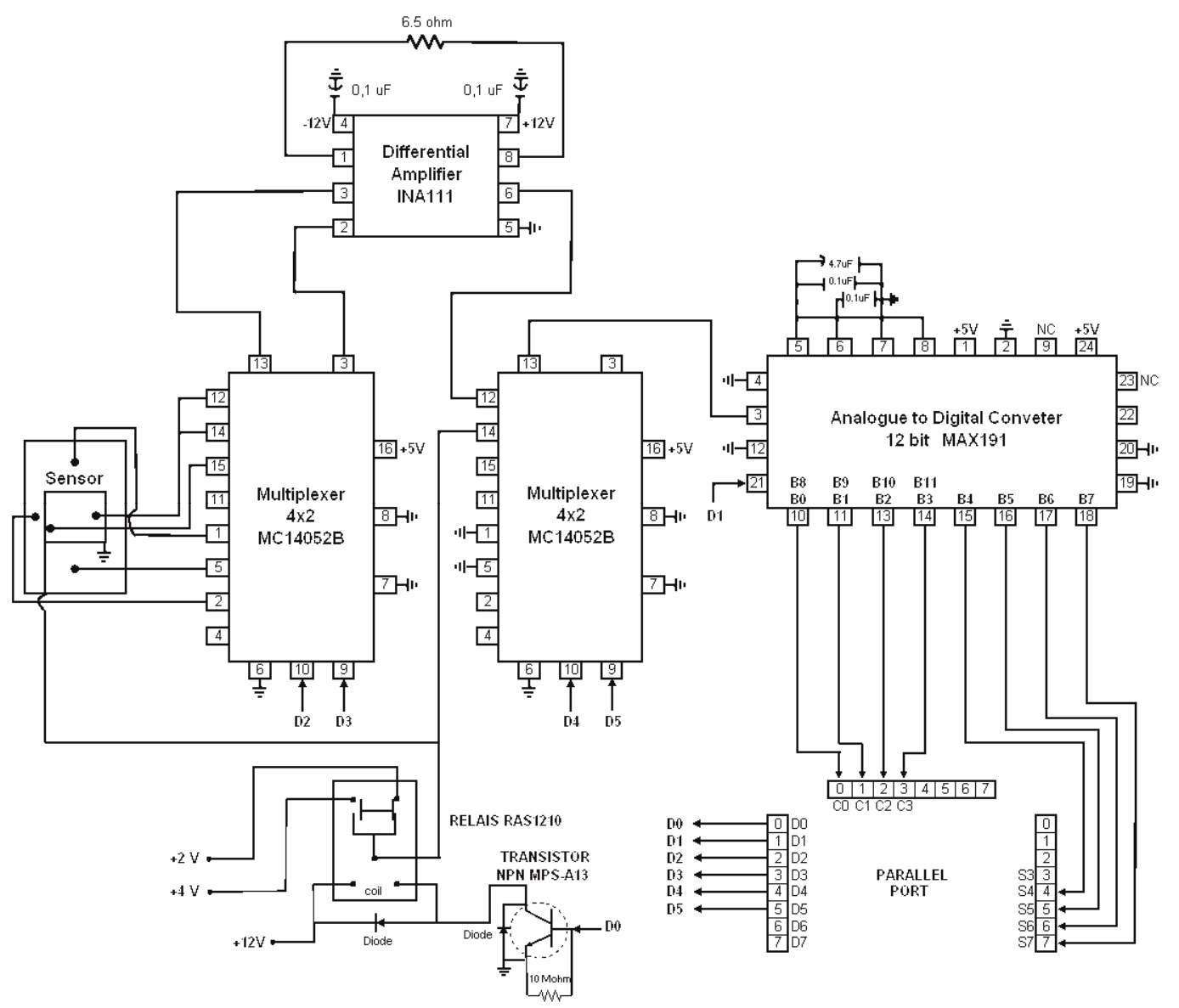

Figure 2. Design of the computer interface card. 
read 12 bits from the analog to digital converter, three reading steps of 4 bits each were implemented in the computer code throughout the control and status buses individualized in Figure 2.

\section{COMPUTER PROGRAM}

A computational code was developed for controlling the system which coordinates the logic input-output signals through the parallel port. The routine includes a set of algorithms that allow to put logical levels of voltage in the output pins and to read the logical values from the input pins of the parallel port. The computational control code makes possible then to act on the multiplexers, the source of dual voltage and the reading of the analog to digital converter. The program sequences the steps for the reading of the sensor data and the calculation of the sap flow at predefined intervals. At the same time it controls the power supplied to the heater in order to reduce the heat at nightly hours and consequently diminishing the chance of damaging the stem of the plant. The computational program was developed in $\mathrm{C}++$ language because even though is a medium level language it allows a simple communication with the hardware devices of the computer. In Figure 3 a block diagram of the computer code that allowed the implementation of real time measurements is schematized. Firstly the necessary variables and archives for calculating the sap flow are declared. Then the reading of the computer parallel port takes place in order to control the operation of data acquisition. The reading is performed first with 4 bits from the control bus then 4 additional bits from the status bus and finally the last the 4 bits again from the control bus necessary to complete the whole 12 bit reading of the analog to digital converter. This operation is repeated three times (one for each differential of temperature) and a fourth time to obtain the reading of voltage of the heater. Table 1 shows the combination of digital signals that allows the reading of the parallel port.

The readings are associated to the registry variables $T_{u}, T_{d}$ and $T_{r}$ of Equation [1] and the variable VOLT that corresponds to the voltage applied to the heater all of them being saved in the text file DATOS.TXT. The calculation of the radial conductance $\left(K_{r}\right)$ is made by means of the Equation [3] in which a sequence of 72 groups of daily data are introduced (measured every 20 minutes). Once calculated 72 values of conductance they are ordered in descendent level of magnitude from where it is chosen the average of the three minors values of $K_{r}$. Once obtained $K_{r}$ the sap flow can be calculated by means of the Equation [1] for each set of daily data. Finally using the trapezoidal method the area under the curve of the sap flow versus time is computed which corresponds to the daily transpiration rate $T\left(\mathrm{~g} \mathrm{day}^{-1}\right)$. This estimated total water consumption of the plant during the daytime is stored in the text file FLUJO.TXT.

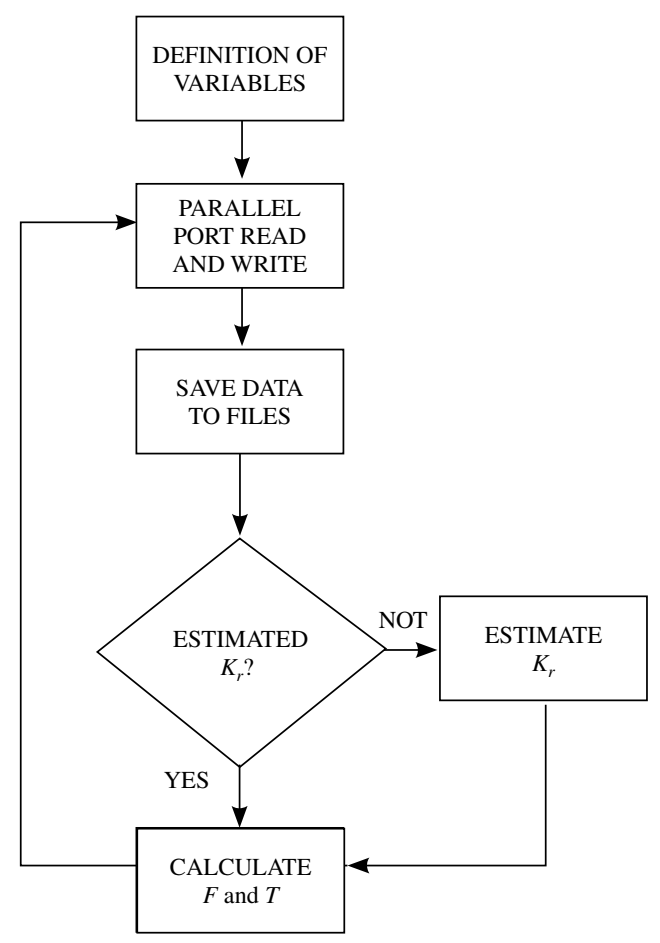

Figure 3. Flow sheet of the computer program.

\section{IMPLEMENTATION OF THE EVALUATION}

The implementation and experimental evaluation of the system were carried out in an environmentally conditioned greenhouse, located in dependencies of the Faculty of Agricultural Engineering in the Chillán Campus of the University of Concepción. The maize plants were cultivated in plastic containers of $20 \mathrm{~cm}$ of diameter and volume of 10 litres. Additionally they were watered and fertilized to assure a suitable growing status that made possible the sap flow evaluations. The measurements were developed during the period in which the plants reached a height of $1.7 \mathrm{~m}$ and a diameter of stem between 23 and $28 \mathrm{~mm}$. 
The evaluation of the plant transpiration was carried out using three different methods in parallel as it is illustrated in Figure 4. The first of the methods corresponds to the lysimetry procedure in which the container with the plant was weighted on an electronic scale Gibertini model TMB 25 AR with a resolution of $0.1 \mathrm{~g}$. A serial interface between the scale and the computer allowed taking measurements every 20 minutes. The second method used was the most popular and widespread methodology which is a data acquisition system (20X dates to logger Campbell Scientific) programmed for taking data every 20 minutes and later saving it in memory. From the logger memory the data was collected and then processed by means of an electronic sheet to obtain the value of transpiration. The third flow metering method utilized the system developed in this research. The proposed system includes an interface card between the sensor and the computer along with software to communicate the sensor with the computer in real time. With the proposed methodology the readings of the sap flow sensor that correspond to differentials of temperatures are stored directly in the computer and used for continuous computation of plant transpiration. Once the transpiration data for eight days of monitoring was generated, a statistical analysis was carried out to evaluate the behaviour of the proposed system with respect to the alternative methods by means of the index $R_{D}$ meaning the relative daily sap flow difference:

$$
R_{D}=\frac{\left(\sum_{i=1}^{i=n}\left(\text { Dobs }_{i}-\text { Dest }_{i}\right)^{2} / n\right)^{1 / 2}}{\overline{D o b s}}
$$

Where $\operatorname{Dobs}_{i}$ is the i-th sap flow observed value, Dest $_{i}$ is the i-th estimated value, $\overline{\text { Dobs }}$ is the average of $n$ observed values and $n$ is the number of measured values.

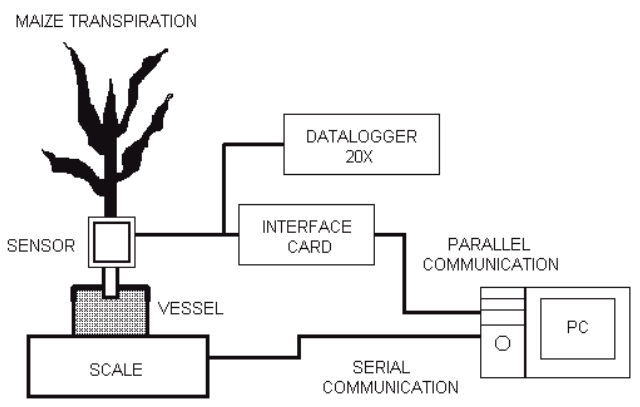

Figure 4. Diagram of the equipment used in the evaluation.

\section{RESULTS AND DISCUSSION}

\section{CALIBRATION OF THE TRANSDUCER}

In order to develop a highly exact correlation between the digital reading and the thermocouple, temperature differential measurements both analog and digital were done. The test was carried out using a copper-constantan thermocouple of 0.13 $\mathrm{mm}$ diameter whose characteristic relationship between tension and temperature is shown in Figure 5. The interface card was connected to the computer and in parallel to an equipment of data acquisition (data logger) programmed to read the thermocouple tension differential in $\mathrm{mV}$. This experience allowed correlating the 12 bit digital reading equivalent to the decimal range from 0 to 4095, with the analog thermocouple tension that varied between -0.1 and $3.5 \mathrm{mV}$, which permits to replace the expensive data acquisition equipment by the interface card system.

\section{EVALUATION OF THE SYSTEM}

In Figure 6 a comparison between the heat flow applied to the heater obtained with the data logger and the proposed system is depicted. From observance of Figure 6 it is notorious the close output approximation between the interface card and the data logger in assessing the value of the power supplied to the sensor.

For the same experience in Figure 7 the value of the instantaneous transpiration considering the three methods: lysimetry, data logger and the interface card are plotted for a period of 24 hours of testing. Curves corresponding to the data logger, the proposed system and lysimetry are very similar however a response delay is exhibited by the first two systems due to the natural resistance effect to water transport in the plant. A similar behaviour of the system can be found in research made by Devit and Berkowitz (1993) and Gutiérrez et al. (1994). Another way to look at the sap flow data is presented in Figure 8 for the same experience where the daily accumulated water volume transpired is shown. It is interesting to realize the close agreement in the total transpiration with the three methods at the end of the day. The main comparison indicates that global operation of the proposed system composed of interface card and computer code, compares favourably with the measurements obtained by either lysimetry or 


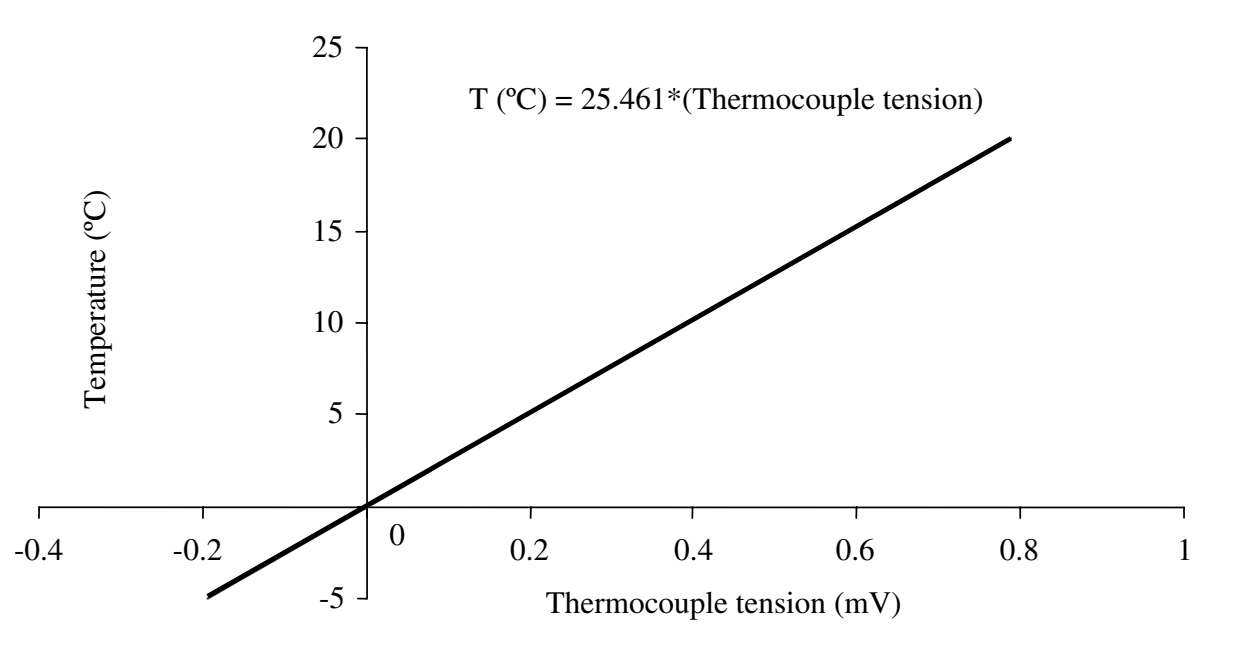

Figure 5. Characteristic of the thermocouple T, Cu-Constantan $0.13 \mathrm{~mm}$

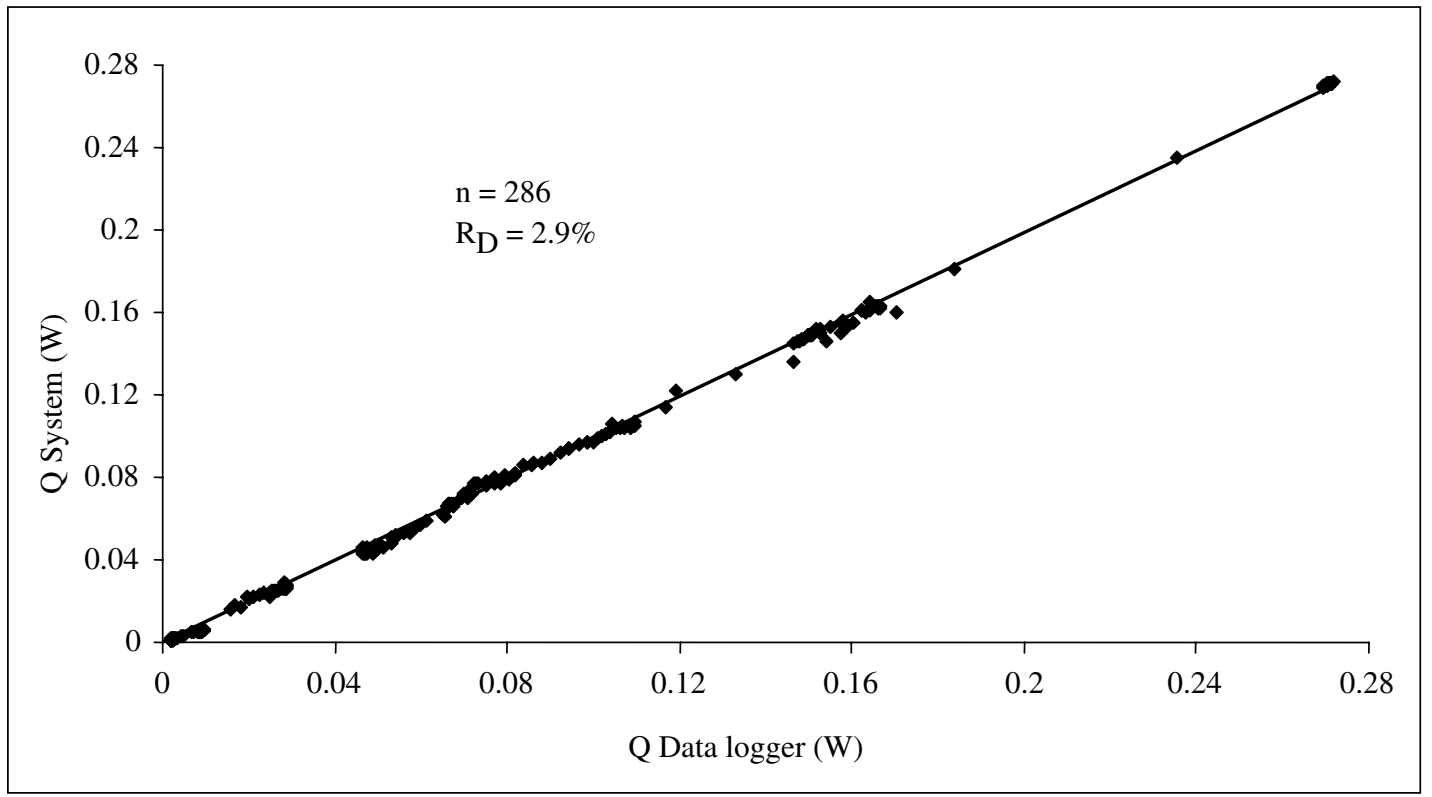

Figure 6. Comparison between the power (Q) supplied to the transducer obtained with the data logger and the proposed system.

typical data acquisition equipment as confirmed in Figure 9. The sap flow relative difference $\left(R_{D}\right)$ of the data logger with respect to lysimetry for eight days of testing was $6,63 \%$, whereas the relative difference of the real time system proposed with respect to lysimetry was $7.74 \%$. These values are considered acceptable for automation purposes in practical irrigation applications, and are similar to those obtained through experimental studies by
Steinberg et al. (1990), Gutiérrez et al. (1994) and Kjelgaard et al. (1997).

\section{CONCLUSIONS}

The design of the interface circuit satisfactorily fulfilled the tasks of processing the signals captured by the sap flow sensor and the reliable transference 


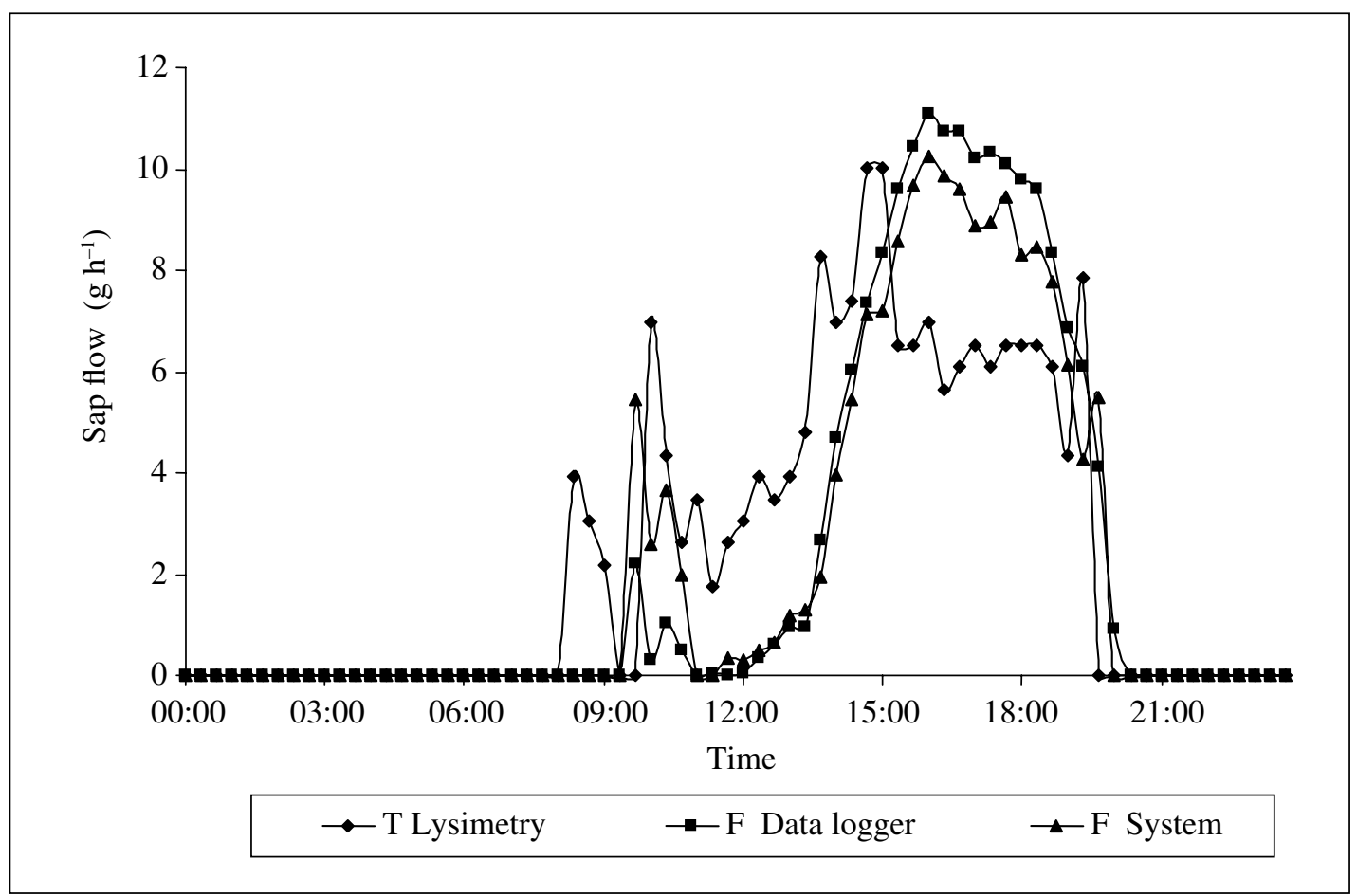

Figure 7. Estimated sap flow by the data logger and the proposed system and the instantaneous transpiration using the lysimetry method for a $24 \mathrm{~h}$ period.

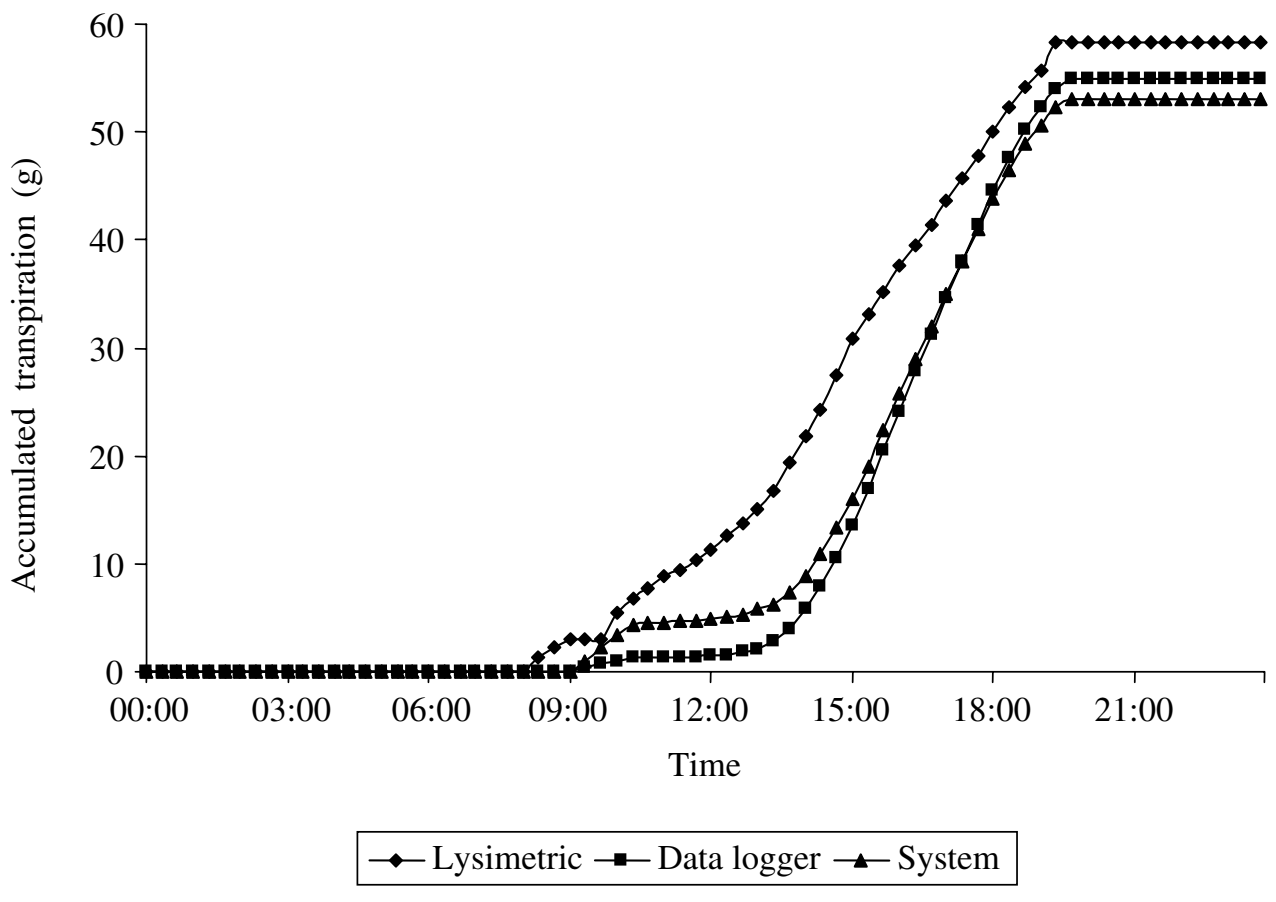

Figure 8. Accumulated transpiration obtained with the data logger, the proposed system and the lysimetry method for a $24 \mathrm{~h}$. period 


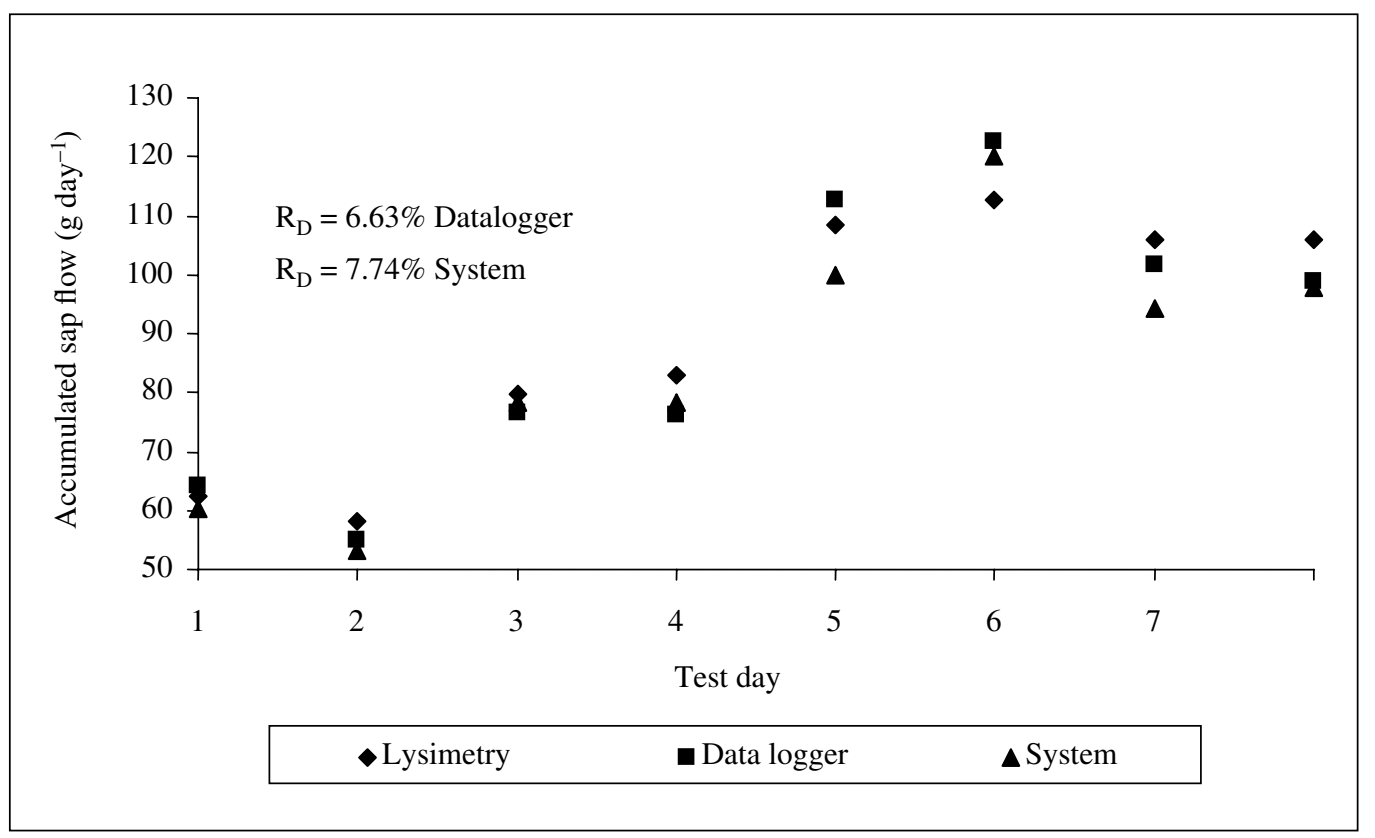

Figure 9. Daily transpiration measured by lysimetry and estimated with the data logger and the proposed system.

of digital data from the card to the computer. The computational program performed adequately in sending control signals to the card along with reading and processing the data permitting an adequate average estimation of a maize plant transpiration. With regards to the experimental evaluation of the system to measure the sap flow the system delivers an average error of $7.74 \%$ in estimating transpiration, similar to the error obtained using expensive data acquisition equipment. After eight days of testing the designed instrumentation prototype exhibited trustworthiness and reliability to estimate plant transpiration in greenhouses. At the same time its architecture involves appropriate features to incorporate remote communication technology, enabling a more versatile use of the device in the open field.

\section{REFERENCES}

ALLEN, R.G.; PEREIRA, L.S.; RAES, D.; SMITH, M. 1998. Crop evapotranspiration: Guidelines for computing crop water requirements. Irrigation and Drainage Paper 56. Food and Agriculture, Organization of the United Nations. Rome. 300 p.

CERMAK, J.; DEMI, M.; PENKA, M. 1976. Improvement of the method of sap flow rate determination in full-grown trees based on heat balance with direct electric heating of xylem. Biol. Plant., 18: 105-110.

DEVITT, D.A.; BERKOWITZ, M. 1993. Estimating transpiration for three woody ornamental tree species using stem-flow gauges and lysimetry. Hortscience 28 (4): 320-322.

GONZÁLEZ, P.C. 2000. Determinación de transpiración de tomates en invernadero. Memoria de Título Ing. Civ. Agríc. Univ. de Concepción. Fac. Ing. Agrícola. Chillán, Chile.

GRANIER, A. 1985. Une nouvelle méthode pour la mesure du flux de seve brute dans le tronc des arbres. Ann. Sci. for., 1985, 42 (2): 193-200.
GREEN, S.; CLOTHIER, B.; JARDINE B. 2003. Theory and practical application of heat pulse to measure sap flow. Agron. J. 95: 1371-1379.

GUTIERREZ, M.V.; HARRINGTON, R.A.; MEIZER, F.C.; FOWNES, J.H. 1994. The effect of environmentally induced stem temperature gradients on transpiration estimates from the balance method in two tropical woody especies. Tree Physiology 14: 179-190.

HERZOG, K. M.; THUM, R.; ZWEIFEL, R.; HÄSLER, R. 1997. Heat balance measurements-to quantify sap flow in thin stems only? Agric. For. Meteorol., Volume 83, Issues 1-2, January 1997, pp. 75-94.

HESS, D. 1980. Fisiología vegetal. Ediciones Omega, S.A. Barcelona.

HINCKLEY, M.; BROOKS, J.R.; CERMAK, J.; CEULEMANS, R.; KUCERA, J.; MEIZER, F.C.; ROBERTS, D.A. 1994. Water flux in hybrid poplar stand. Tree Physiology 14: 1005-1018. 
JELDRES, R. 2000. Diseño y evaluación de un medidor de flujo de savia para estimar transpiración de eucalyptus sp. Memoria de Título Ing. Civ. Agríc Univ. de Concepción. Fac. Ing. Agrícola. Chillán, Chile.

KJELGAARD, J.F.; STOCKLE, C.O.; CAMPBELL, G.S. 1997. Measuring sap flow the heat balance approach using constant and variable heat inputs. Agricultural and Forest Meteorology 85: 239-250.

REYES, J.F.; JARA, J.; JELDRES, R. 2007. Design parameters evaluation of a sap flow meter for small trees. IDESIA 25 (1): 53:62.
RÍOS, D.C. 1999. Evaluación de transpiración en lilium bajo cultivo forzado. Memoria de Título Ing. Civ. Agríc Univ. de Concepción. Fac. Ing. Agrícola. Chillán, Chile.

STEINBERG, S.; VAN BAVEL, C.H.M.; MCFARLAND, M.J. 1989. A gauge to measure mass flow rate of sap in stems and trunks of woody plants. Journal of the American Society for Horticultural Science 114 (3): 466-472.

STEINBERG, S.; VAN BAVEL, C.H.M.; MCFARLAND, M.J. 1990. Improved sap flow gauge for woody and herbaceous plants. Agronomy Journal 82: 851-854.

SWANSON, R.H. 1994. Significant historical developments in thermal methods for measuring sap flows in trees. Agricultural and Forest Meteorology 72: 113-132. 